has proceeded, will remain in being, and the finds are to be handed over to the Corporation of St. Albans. The present investigations at St. Albans have occupied three years. The results, as was anticipated from the importance of Verulamium in the polity of early Britain, have been as fruitful as any ever obtained from a Romano-British site, and, in fact, have exceeded expectation. They fully justify the necessarily heavy expenditure; and a correspondingly heavy burden of gratitude is laid on the learned world to Dr. and Mrs. Wheeler and their assistants, as well as to the Excavations Committee and the Corporation of St. Albans, through whom they were made possible. While there can be no doubt that the means will be forthcoming for continuing the investigation in due season, an intermission, provided it be not too long, is by no means entirely a misfortune. These three years of excavation have produced a mass of material which demands a breathing space for its proper digestion.

\section{Romano-British Pottery}

A KNOWLEDGE of the names of the potters by whom the pottery found on Romano-British or British sites was made is obviously of great value to the archæologist in the interpretation of the ceramic evidence. If the site of the potter's factory is known, as it is in many instances, it serves to indicate the trend of cultural and commercial relations. Among the firstfruits of this season's excavations at Colchester has been the identification of names of two potters inscribed on the 'Samian' (Terra Sigillata) ware. Examples of these makers' ware had previously been found at both Colchester and Verulamium. There are, however, indications that evidence may be forthcoming pointing to a local factory, thus confirming the view that Samian ware was manufactured in Britain as well as imported. In the study of Samian ware, Dr. Felix Oswald's "Stamps on Terra Sigillata" (privately printed, 1931) is indispensable; but although every effort was made to make that list complete, additions, whether from excavation or from examples in museums, are bound to come to light from time to time. A considerable number of examples not recorded in Dr. Oswald's lists, though all by previously known potters, will be found in a "Catalogue of Potters" Stamps on Terra Sigillata found in Gloucester", by Mr. Charles Green, curator of the Gloucester Museum (Public Museum, Gloucester, Occasional Papers No. 1. Price 6d.), which has recently been issued by the Museum authorities. There are in all fifty-six specimens, ranging in date from Nero to Antonine. The pre-Flavian and Flavian stamps are all of South Gaulish potters. Thirty-nine come from central Gaul and three from eastern Gaul.

\section{Archæological Exploration on Monte Alban, Mexico}

A Dispatch from Mexico City addressed to Science Service, Washington, announces that Señor Alfonso Caso, who is in charge of the exploration of the ruins on Monte Alban, Oaxaca, proposes in the coming season to open up the great "South Terrace" of the acropolis, which is regarded as in all probability the most important part of the site. It has been left unexplored up to the present in order that the work may be carried out in the light of experience on the site. The acropolis is a tableland on top of the mountain, approximately a third of a mile long. The "North Platform" was explored last year. The "South Terrace", judging by the contours under the earth covering it, should be richer in remains than any part explored up to the present. Mounds superimposed upon mounds make this the highest point on Monte Alban. At the south-east corner is a mound with a hollow rotunda, which the late Mrs. Zelia Nuttall held to be an astronomical observatory, and considered the most important monument in Mexico in view of its relation to the calendar cultures of America.

\section{South African Wild Flowers}

AN exhibition of South African wild flowers is to be arranged under the auspices of the Royal Horticultural Society on October 24 and 25. This exhibition, which is to be opened by H.R.H. Princess Alice, Countess of Athlone, has been organised by an influential committee in South Africa and with the official patronage and co-operation of the High Commissioner for the Union of South Africa in London. A remarkable range of wild flowers, aloes and succulents, collected from twenty different districts in South Africa, has been dispatched, and the exhibition will provide the most representative and complete display of flora ever sent overseas from this Dominion. It will include many species of great beauty and rarity. Notable among the displays will be the remarkable variety of heaths, such as mealie heath (Erica abietina); dark-mouthed heath ( $E$. sacciflora); red and yellow heath ( $E$. exsurgens); Walker's heath ( $E$. Walkeria); pink drooping bell heath (E. propendens); riversdale orange-and-green heath ( $E$. blenna); many varieties of everlastings ; grasses; orchids; numerous varieties of proteas, such as woolly-bearded protea (Protea bargigera); giant or king protea ( $P$. cynaroides); and the pincushion protea ( $P$. leucosperum); specimens of bulbous plants, gladioli, succulents and aloes. The greatest care in handling and in the regulation of temperatures has been necessary in picking, packing and conveying these floral treasures from South Africa for their long journey of 6,000 miles to London. This in itself will make the exhibition noteworthy. The exhibition will be staged in the Royal Horticultural Society's Hall in Vincent Square, S.W.1, at the same time as the Society's Orchid Show in the new Hall ; tickets of admission to either display will permit of entry to both halls.

\section{Electrical Accidents in 1932}

THE report on electrical accidents in Great Britain for 1932 (London : H.M. Stationery Office, $4 d$.) is both interesting and full of useful information. The total number of electrical fatalities due to electricity last year was 70 , of which 14 occurred in premises of a domestic character. It is stated that there are fewer 
accidents in Great Britain than elsewhere. The electrical industry is one of the few major industries which has remained active during the past fow years. Em. ployment on the supply side increased by 50 per cent between 1924 and 1930. Notwithstanding this increase in the number of employees the number of fatalities remains practically the same. It is well for employers and occupiers to remember the law as recently laid down in High Court decisions that it is their duty to protect the workmen against their own errors, and it may be their own folly. It is not sufficient merely to give a warning. Although trade depression has been acute, the re-equipment of textile mills has been steadily progressing and the applications of electricity in factories is still increasing. Foreign firms have started branches in Great Britain which are fully equipped electrically. Luminous tubes are coming rapidly into use and although their manufacture involves high pressure, there is almost a complete absence of accidents. Several accidents from severe shock have been reported where the prompt use of artificial respiration probably saved the injured persons' lives.

\section{History and Development of Electric Power}

THE history and development of electric power has recently been reviewed in a handbook by W.'T. O'Dea (South Kensington, Science Museum Handbooks. "Electric Power", Part I, "History and Development". London: H.M. Stationery Office, 1933. $2 s$. net). This handbook should prove of the greatest value to inventors of electrical devices. An excellent historical account is given of the development of the various sections of the electrical industry. Notable apparatus illustrating the various stages in the development of the art and represented in the Museum by originals or replicas are indicated by asterisks. Anyone therefore who has read this book beforehand will be able to derive the full benefit from a visit to the Museum. Clearly printed photographs are shown illustrating the latest devices and methods used in engineering ; they include a mercury arc rectifier, high-tension lattice towers, methods of transporting heavy engineering apparatus, etc. Many of the objects exhibited at the Faraday centenary exhibition are now included.

\section{Fishes of the Thames Estuary}

IN the Southend Standard of August 24, Mr. A. Laurence Wells writes a very interesting article based on further notes from Dr. Murie's work on the Leigh fisheries. This includes a list of all fishes recorded from the Thames estuary with remarks on each species. Considerable changes have occurred in the fish fauna during the last fow centuries. Long ago salmon were abundant, coming up the river to breed; after 1833 none were seen, the pollution of the river cutting them off from their favourite haunts. Now they are returning since the conditions have been much improved. The salmon trout was far commoner in Elizabethan days than at the present time although a few may still be taken. The smelt fishery used to be much more important than it is now. The Thames sturgeon was celebrated in former years and is still fairly common in the estuary. Some fishes come for breeding purposes, others occur only as iry, many are permanent inhabitants or regular seasonal visitors. The herring in late summer forms 80 per cent of the whitebait; there are no less than fifteen species of the flat-fish family, eleven of the cod family and six of the herring family, whilst almost every group of fishes is represented. Rarities include specimens of the sword-fish, the pilot-fish and the flying-fish.

\section{Medical Census of Nigeria}

Ww have received two volumes of the medical census of Nigeria, vol. 5, Northern Provinces by Dr. R. C. Jones, and vol. 6, Southern Provinces by Dr. J. G. S. Turner ("Census of Nigeria, 1931". Crown Agents for the Colonies, 1932. 4 Millbank, London, S.W.1. Price 7s. and 8s. respectively). Attention is directed to the difficulties of obtaining reliable data in a native population, so that the results are approximate only. Details are given of the climate, sanitation, and social customs of the districts. The percentage of males and females at all ages are approximately the same. Children are welcome, and the birth-rate is high, 40-55 per 1,000. As might be expected, the infant mortality rate is high, as much as 250-350 per 1,000 births. Smallpox is prevalent, and in some districts more than half the population have suffered attack. The percentage vaccinated varies much, from scarcely any in some areas to 90 in other areas. Malaria is hyperendemic and there is some leprosy. A note on the covers of the volumes of the census states that an insecticide has been used in the binding so as to render them impervious to the ravages of insects.

\section{Recent Earthquakes in China}

Between August 23 and 31, a series of destructive earthquakes occurred in the northern part of the province of Szechuan. In the valley of the Min, a tributary of the Yangtze, great damage was caused in the portion between Sungtan and Mowchow. According to a message in the Times for September 20, the earthquake was accompanied by a sudden upheaval of the bed of the Min, by which its waters were made to flow upstream. One member of the series was probably that recorded at West Bromwich on August 25, the greatest registered there during the last six months. In past times, and especially just before and after the beginning of the Christian era, the province was frequently visited by destructive earthquakes that gave rise to many landslips among the mountains. On two occasions, in 26 and 10 B.C., these landslips obstructed the flow of the River Min.

\section{Empire Marketing Board's Film Library and Cinema}

A SIDE-LINE of the activities of the Empire Marketing Board, which came to an end on September 30, was the collection of a valuable library of instructional films and the maintenance of a cinema at the Imperial Institute. A few days ago it was announced that the 